\title{
Peranan Pajak dalam Perekonomian Indonesia
}

\author{
Oleh : Hudiyanto
}

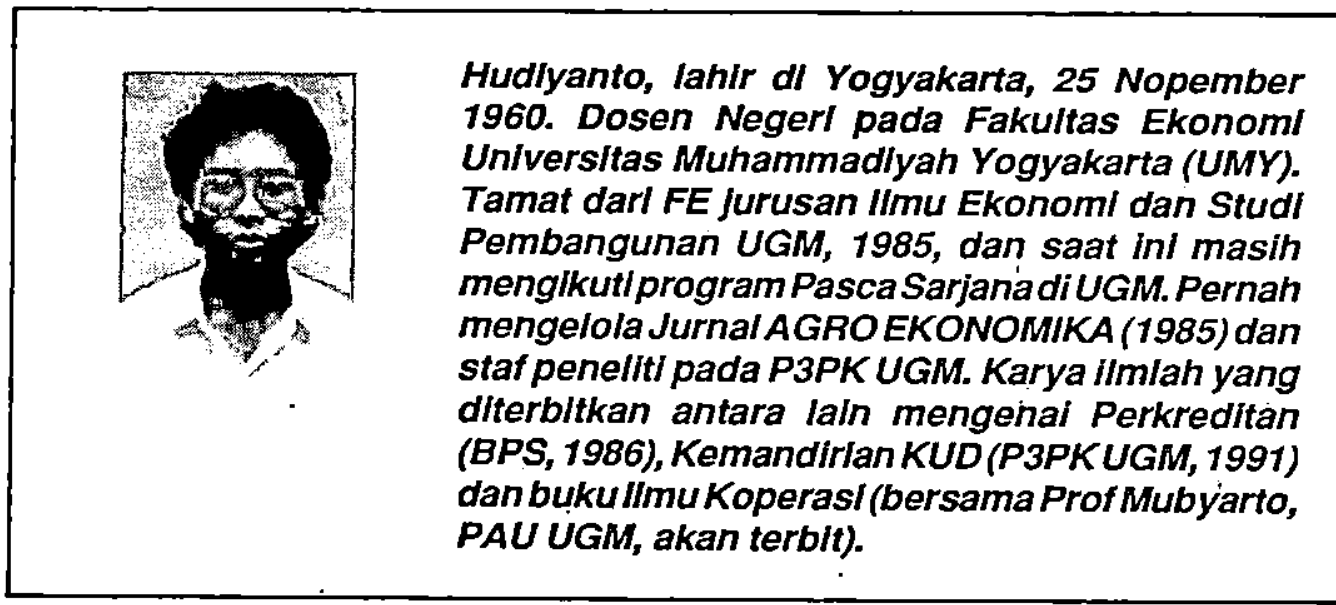

Pendahuluan

Dalam upayanya untuk mencapai target pertumbuhan ekonomi yang lebih baik dari periode sebelumnya dan. sekaligus tetap terjaga stabilitasnya harga, maka kebijaksanaan APBN (Anggaran Pendapatan dan Belanja Negara) selalu berpedoman kepada prinsip anggaran yang berimbang dan dinamis. Oleh karena situasi ekonomi dunia masih saja memperlihatkan gejolak yang secara langsung akan mempengaruhi perekonomian Indonesia lewat pengaruhnya pada penerimaan ekspor, maka kebijaksanaan APBN semenjak tahun-tahun 1980-an ditempuh dengan cara yang relatif ketat. Penerimaan dari sektor minyak dan gas (migas) yang secara langsung tergantung kepada perekonomian dunia yang tidak stabil mendorong peningkatàn upaya mengembangkan sumber penerimaan negara dari luar sektor migas.

Kebijaksanaan APBN yang ketat menunjukkan adanya upaya penghematan. Dalam hal penerimaan upaya itu dilakukan lewat peningkatan penerimaan dalam negeri khususnya penerimaan di luar minyak dan gas bumi yaitu dengan cara mengintensifkan pungutan pajak dan memperluas sumber-sumber penerimaannya; Sedangkan dalam hal pengeluaran maka pemerintah menghemat pengeluaran rutin dan pembangunan dengan mengurangi subsidi yang diberikan kepada konsumen lewat komoditas tertentu yaitu pupuk dan bahan bakar minyak.

Pajak dalam Perekonomian Nasional

Sementara itu untuk mendukung 
upaya penerimaan dalam negeri dari sektor paják maka ditempuh berbagai kebijaksanaan terutama yang dikenal dengan reformasi di bidang perpajakan dengan diundangkannya berbagai UU yang berkaitan dengan bidang perpajakan ini. Dengan dilancarkannya berbagai upaya untuk tidak terlalu bergantung kepada sektor migas itu maka intensifikasi dan ekstensifikasi penarikan pajak dilakukan, sehingga peran pajak dalam penerimaan dalam negeri selalu meningkat sebagaimana ditunjukkan dalam tabel 1 . angka 45 persen. Hal ini dipengaruhi disamping oleh keadaan perekonomian dunia yang memaksa penerimaan dalam negeri dari sektor minyak dan gas bumi (migas) mengalami kemerosotan, juga disebabkan oleh ekstensifikasi dan intensifikasi penarikan pajak dari masyarakat.

Peningkatan peran pajak mempunyai implikasi yang penting terutama karena peningkatan peran itu juga berarti pajak akan menjadi instrumen kebijaksanaan

Tabel 1 Penerimaan Dalam Negeri, Penerimaan dari Migas, Dan Penerimaan di Luar Migas, 1981 - 1990

\begin{tabular}{|c|c|c|c|c|c|c|c|c|c|c|}
\hline & $\begin{array}{c}1981 / \\
82\end{array}$ & $\begin{array}{c}1982 / \\
83\end{array}$ & $\begin{array}{c}1983 / \\
84\end{array}$ & $\begin{array}{c}1984 / \\
85\end{array}$ & $\begin{array}{c}1985 / \\
86\end{array}$ & $\begin{array}{c}1986 / \\
87\end{array}$ & $\begin{array}{c}1987 / \\
88\end{array}$ & $\begin{array}{c}1990 / \\
91\end{array}$ & $\begin{array}{c}\left.1991 /^{*}\right) \\
92\end{array}$ & $\begin{array}{c}\left.1992 /{ }^{*}\right) \\
93\end{array}$ \\
\hline $\begin{array}{l}\text { Penerimaan Dlm.Neg. } \\
\text { Penerimaan dari } \\
\text { pajak non migas } \\
\text { Persentase pajak } \\
\text { dari Pen. Total }\end{array}$ & $\begin{array}{r}12.213 \\
3.585 \\
(29)\end{array}$ & $\begin{array}{l}12.418 \\
4.248 \\
(34)\end{array}$ & $\begin{array}{r}14.433 \\
4.913 \\
(34)\end{array}$ & $\begin{array}{r}15.905 \\
5.475 \\
(35)\end{array}$ & $\begin{array}{r}18.678 \\
7.518 \\
(40)\end{array}$ & $\begin{array}{r}19.253 \\
8.108 \\
(42)\end{array}$ & $\begin{array}{r}17.833 \\
8.095 \\
(45)\end{array}$ & $\begin{array}{r}31.583 \\
20.800 \\
(66 .)\end{array}$ & $\begin{array}{r}40.184 \\
25.175 \\
(63)\end{array}$ & \\
\hline
\end{tabular}

*) RAPBN

Sumber : Bank Indonesia, Laporan Tahunan, berbagai tahun

Dari Tabel 1 nampak bahwa peranan sektor pajak dalam penerimaan dalam negeri relatif rendah pada tahun 1981 yaitu hanya 29 persen dari total penerimaan dalam negeri. Tetapi peranananya mulai mengalami kenaikan yang cukup berarti setelah tahun 1982 yaitu mencapai 34 persen dari total penerimaan dalam negeri dan mengalami pelonjakan pada tahun 1986 dan tahuntahun berikutnya yang mencapai diatas yang semakin penting. Karena pajak berkaitan dengan disposable income maka ia berkaitan dengan multiplier effect atau - angka pengganda perekonomian. Dengan demikian intensifikasi penarikan pajak juga berarti berpengaruh terhadap angka pengganda perekonomian. Termasuk dalam hal ini adalah pengaruhnya nanti terhadap iklim investasi dan anggaran berimbang yang di anut oleh pemerintah. 
Kebijaksanaan di bidang perpajakan

Dalam literatur ekonomi pajak merupakan komponen yang amat penting dalam menjalankan roda perckonomian (Boadway, 1986). Ia merupakan alat bagi pemerintah untuk melakukan kebijakan fiskalnya, yaitu untuk mempengaruhi aktifitas ekonomi dalam masyarakat. Apabila pemerintah merasa bahwa perekonomian tumbuh terlaiu cepat maka ia bisa mengendalikannya dengan pengetatan penarikan pajak (kebijaksanaan kontraksi). Sedangkan dalam hal perekonomian tumbuh dengan lambat maka pemerintah bisa ikut campur tangan lewat kebijaksanaan yang bersifat ekspansif.

Terdapat beberapa faktor yang menyebabkan pemerintah melakukan intervensi dalam suatu perekonomian (Boadway et.al, 1984). Dalam kondisi pasar persaingan sempurna, dengan berbekal informasinya yang lengkap, dan semua pihak bebas melakukan apa yang diinginkan (laissez faire), maka perekonomian dengan sendirinya akan selalu mengalokasikan barang dan faktor produksinya secara efisien. Tetapi dalam kondisi pasar tidak sempurna, masalah efisiensi menjadi masalah yang harus diselesaikan oleh pemerintah. Dengan-alasan seperti inilah maka pemerintah berhak untuk campur tangan dalam perekonomian. Dengan tindakan campur tangannya pemerintah berambisi untuk menyelesaikan masalah yang timbul dari adanya barang publik, munculnya eksternalitas dalam proses produksi, selalu terjadinya kemungkinan resiko dan ketidakpastian, adanya pasar yang bekerja tidak efisien, dan selalu munculnya masalah distribusi pendapatan dalam pembagian output nasional (Boadway, 1984). Yang memungkikan pemerintah untuk menyelesaikan masalahi tersebut adalah karena dalam sistem perekonomian modem pemerintah mempunyai fungsi yang jauh lebih.luas dibandingkan dengan fungsinya menurut kaum klasik dalam pemikiran ekonomi. Fungsi pemerintah pada masa sekarang meliputi Pertama, fungsi untuk mengalokasikan output dan sumberdaya; kedua, fungsi pemerintah untuk melakukan distribusi kemakmuran bangsa; ketiga fungsi untuk melakukan stabilisasi perekonomian. (Musgrave, 1987)

Dalam kaitan ini, meskipun pemerintah "dibenarkan" untuk menarik pajak dari masyarakatnya untuk membiayai pembangunan, tetapi dibandingkan dengan banyak negara yang lain, pemerintah Indonesia terkesan "tidak sungguh-sungguh" dalam menggali sumber pajak ini (Uppal, 1986) paling tidak sampai awal delapan puluhan. Hal itu terlihat dari Tabel 2 yang membandingkan penerimaan pajak oleh beberapa negara dihitung penerimaan pajak per kapita. 
Tabel 2 Penerimaan Pajak Menurut Jenis Pajak

Sebagai Proporsi dari GDP, 1978-1980

\begin{tabular}{|c|c|c|c|c|c|c|c|}
\hline Negara & $\begin{array}{c}\text { GNP per } \\
\text { kapita }\end{array}$ & $\begin{array}{l}\text { Pajak } \\
\text { pend. }\end{array}$ & $\begin{array}{l}\text { Pajak } \\
\text { penj. }\end{array}$ & $\begin{array}{l}\text { Exise } \\
\text { tax }\end{array}$ & $\begin{array}{l}\text { Duty } \\
\text { impont }\end{array}$ & $\begin{array}{l}\text { Duty } \\
\text { exp. }\end{array}$ & $\begin{array}{c}\text { PjK. } \\
\text { proper }\end{array}$ \\
\hline Indonesia & & & & & & & \\
\hline 1980 & 370 & & & & 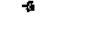 & & \\
\hline 1982 & 625 & 0,42 & 1,09 & 1,95 & 1,01 & 0,8 & 0,32 \\
\hline Rata-rata 21 Negara dengan & & $12 ?$ & 171 & 163 & & 162 & 026 \\
\hline GDP Kurang aan $\gg 300$ & 200 & 1,22 & 1,11 & 1,03 & $4 \sqrt{2}$ & 1,02 & 0,20 \\
\hline $\begin{array}{l}\text { Rata-rata } 43 \text { negara dengan } \\
\text { GDP } \$ 300-\$ 600\end{array}$ & 510 & 190 & 154 & 25 & 2,8 & 1.15 & 0.37 \\
\hline
\end{tabular}

Sumber : (Uppal, 1986)

Dari Tabel 2 nampak bahwa dibandingkan dengan negara-negara dengan GDP yang lebih rendah hasil penarikan pajak dari masyarakat Indonesia masih tertinggal. Untuk pajak kekayaan yang merupakan fungsi dari pendapatan nasional misalnya, Indonesia hanya menunjukkan angka 0,42 \% sementara negara dengan pendapatan yang lebih rendah mencapai lebih dua kali lipatnya yaitu 1,22 dan dibandingkan dengan negara yang sederajat tingkat GDP-nya, hanya seperempatnya, yaitu $1,90 \%$. Kesimpulannya adalah bahwa Indonesia tidak banyak menggunakan pajak sebagai sumber penerimaannya.

Rendahnya penerimaan pajak tersebut bisa dilacak dari elastisitas penerimaan pajak dari pendapatan sebagaimana bisa dilihat perbandingan antar negara dalam Tabel 3.

Tabel 3 Elastisitas Penerimaan Pajak dari Pendapatan Nasional, 1976 - 1982

\begin{tabular}{|c|c|}
\hline Negara & $\begin{array}{c}\text { Elastisitas Penerimaan Pajak } \\
\text { Pendapatan }\end{array}$ \\
\hline India & 2,5 \\
\hline Korea & 2,2 \\
\hline Honduras & 2,1 \\
\hline Maroko & 2,2 \\
\hline Pakistan & 1,9 \\
\hline Malaysia & 1,9 \\
\hline Indonesia & 1,8 \\
\hline
\end{tabular}

Sumber: World Bank : Indonesia Policies Prospect for Economic Growth, 1984 dan Raja Chelliah, "Trends in Taxation in Developing Countries dalam M Frd, Readings on Taxations in Developing Countrles, Dikutip dari JS Uppal, EKI, 1986. 
Rendahnya angka pajak Indonesia per kapita itu disebabkan oleh sistim perpajakan yang kurang mendukung sehingga penarikan pajak masyarakat kurang efektif. Tingkat pengelaan pajak secara legal (tax avoidance) dan pengelaan secara tidak legal (tax evasion) dengan demikian menjadi cukup tinggi. Hal ini nampak dari Tabel 4 yang menunjukkan tingkat realisasi penerimaan pajak dibandingkan dengan penerimaan pajak yang ditargetkan.
Reformasi di bidang perpajakan

Dalam kaitan itu pemerintah telah mempengaruhi sistem perpajakan yang berlaku selama ini. Sistem perpajakan yang baru itu terdiri dari undang-undang tentang Ketentuan Umum dan Tata Cara Perpajakan (UU No. 6/1978), UndangUndang tentang pajak Penghasilan (UU No. 7/1983), Undang-Undang tentang Pajak Pertambahan Nilai Barang dan Jasa dan pajak penjualan atas Barang Mewah

Tabel 4. Realisasi Pajak dari Potensi Pajak Yang Sebenarnya.

\begin{tabular}{|lc|}
\hline JENIS PAJAK & $\begin{array}{c}\text { REALISASI PAJAK DARI PAJAK } \\
\text { POTENSIAL }\end{array}$ \\
\hline Pajak Pendapatan & 16 \\
Pajak Kekayaan & 14 \\
Pajak Penjualan & 33 \\
Pajak Excise & 34 \\
Pajak Penjualan Impor & 23 \\
Tarif Impor & 31 \\
IPEDA & 20 \\
Rata-rata & 28 \\
\hline
\end{tabular}

Sumber : Lerche, 1980, halaman 39

Dari Tabel 4 nampak bahwa rata-rata penarikán pajak dari potensi yang sebenarnya hanya 28 persen. Dari uraian tersebut maka bisa disimpulkan bahwa potensi pajak belum dimanfaatkan secara optimal untuk membiayai pembangunan. Keadaan ini kemudian cukup terasa ketika bonanza (rejeki nomplok) dari minyak bumi menunjukkan kesuramannya pada tahun 1980-an, yang kemudian menyebabkan pemerintah menyadari bahwa penarikan pajak secara efektif (bukan hanya dari pajak minyak) cukup penting untuk dilakukan.
(No. 8/1983) dan Undang-Undang tentang Pajak Bumi dan bangunan (PBB).

\section{Pajak penghasilan}

Undang-undang Pajak Penghasilan 1984 untuk menggantikan 1925, UU PBDR tahun 1970 dan UU No. 8 tahun 1967 tentang MPO dan MPS pada dasarnya merupakan upaya untuk meningkatkan penerimaan dalam negeri dari sektor pajak. Undang-undang yang mulai diberlakukan pada 1 Januari itu pada dasarnya menyederhanakan dan 
menurunkan tarif pajak rata-rata. Tujuan dari kebijaksanaan itu adalah untuk mendorong partisipasi masyarakat dalam membayar pajak kepada negara. Dengan keluamya kebijaksanaan baru itu maka lapisan tarif pajak pendapatan dan pajak perseorangan yang pada peraturan sebelumnya masing-masing terdiri dari 6 dan 10 lapisan dengan kisaran tarif antara 5 persen - 50 persen dan 2,5 persen - 45 persen disederhaakan menjadi 3 lapisan tarif pajak penghasilan yaitu 15 persen untuk penghasilan sampai dengan $\mathrm{Rp}$. $10.000 .000,-, 25$ persen untuk penghasilan Rp. 10.000.000,- sampai Rp. 50.000 .000 ,- dan 35 persen untuk penghasilan diatas Rp. 50.000.000,setehun.

Kebijaksanaan di bidang perpajakan sebagaimana dikemukakan selain dimaksudkan untuk meningkatkan penerimaan negara juga dimaksudkan untuk menciptakan iklim perpajakan yang adil dan menciptakan keringanan beban pajak bagi masyarakat yang berpenghasilan rendah melalui kebijaksanaan peningkatan batas pendapatan Bebas Pajak. Menurut UU Pajak penghasilan 1984 Pendapatan Tidak Kena Pajak (PTKP, istilah lain dari BPBP) bagi wajib pajak dinaikkan dari Rp. 300.000 ,- menjadi Rp. 960.000 ,dan untuk isteri dari Rp. 300.000,menjadi Rp. 480.000,- sedangkan bagi anak dari Rp. 150.000,- menjadi Rp. 480.000,-. Peningkatan PTKP tetapi yang disertai dengan esktensifikasi subyek pajak diharapkan bisa tetap meningkatkan penerimaan pajak oleh pemerintah terutama yang ditarik dari kelompok masyarakat berpenghasilan tinggi. Hal ini menunjukkan tekad pemerintah untuk melepaskan beban pajak pada golongan penghasilan kecil tetapi diikuti dengan intensifikasi penarikan pajak pada golongan penghasilan yang lebih besar.

\section{PPN dan Pajak atas barang mewah.}

Penyederhanaan perpajakan nampak pula dari diundangkannya UU no. 8 tahun 1983 tentang Pajak Pertambahan Nilai barang dan jasa dan pajak Penjualan atas barang Mewah sebagai pengganti dari UU tentang pajak Penjualan tahun 1951. Kebijaksanaan yang baru itu memungkinkan dihindarkannya pemungutan pajak secara berganda. Tarif pajak disederhanakan dari 8 jenis menjadi hanya 2 jenis tarif pajak. Pertama, tarif pajak Pertambahan Nilai (PPN) sebesar 10 persen bagi barang yang dikonsumsi di dalam negeri serta kedua 0 persen untuk barang yang akan diekspor. Tarif itu dengan ketentuan pemerintah untuk PPN bisa diubah menjadi serendah-rendahnya 5 persen dan setinggi-tingginya 15 persen untuk barang-barang yang akan dikonsumsi di dalam negeri. Sedangkan untuk barang-barang mewah yang dikonsumsi di dalam negeri dikenakan pajak Penjualan antara 10 sampai 20 persen tergantung kepada tingkat kemewahan dari barang itu, sementara untuk barang-barang mewah yang akan diekspor dikenakan pajak 0 persen. Meskipun demikian, ketentuan untuk pajak bagi barang-barang mewah yang dikonsumsi di dalam negeri itu bisa diubah menjadi setinggi-tingginya 35 persen. Dengan dikeluarkannya undangundang di bidang perpajakan itu maka diharapkan jumlah penerimaan pajak akan 
meningkat karena sistem perpajakannya lebih sederhana dan lebih pasti dalam pengenaan pajaknya.

\section{Pajak bumi dan bangunan}

Pajak atas Properti juga mengalami reformasi. Iuran Pembangunan Daerah telah diganti dengan Pajak Bumi dan Bangunan dengan diberlakukannya undang-undang mengenai PBB sejak Januari 1986. Nilai Jual Obyek (NJOP) yang merupakan faktor penentu pajak bumi dan bangunan disempurnakan melalui klasifikasi yang disesuaikan perkembangan harga tanah dan bangunan. Dari NJOP kemudian ditetapkan Nilai Jual Kena Pajak (NJKP) yang dengan Peraturan Nomor 46 Tahun 1986 besamya adalah 20 persen dari NJOP. dari NJKP ini maka ditarik pajak yang sama sebesar 0,5 persen dari nilai jual kena pajak.

\section{Bea meterai}

Untuk pajak lainya yaitu bea meterai dan lelang telah dikeluarkan UndangUndang nomor 13 yang antara lain menetapkan tarif Rp. 1.000,- untuk semua dokumen berbentuk perjanjian, akta tanah, akta notaris dan surat yang memuat nilai uang lebih dari Rp. 1 juta. Sedangkan untuk cek dan bilyet giro ditetapkan Rp. 500,-

\section{Cukai}

Kebijaksanaan di bidang cukai yaitu cukai tembakau, cukai gula, cukai bir dan alkohol sulingan juga mengalami perkembangan. Kebijaksanaan di sektor ini terutama diarahkan untuk mendorong produksi dan tetap memperluas kesempatan kerja. Untuk jenis sigaret kretek buatan mesin (SKM) baik yang memakai filter maupun yang tidak memakai filter dengan tingkat produksi terendah 675 juta batang atau kurang tarif cukainya ditetapkan 30 persen per tahun sedangkan untuk tingkat produksi diatas 8,5 milyar dikenakan cukai 37,5 persen pertahun. Sementara itu untuk sigaret putih buatan mesin (SPM) dengan produksi terendah 320 juta batang atau kurang, tarif cukainya dikenakan sebesar 22,5 persen pertahun, sedangkan untuk yang tingkat produksi diatas 10 milyar batang per tahun dikenakan cukai 35 persen per tahun. Untuk sigaret kretek tangan (SKT) dengan tingkat produksi terendah 1,2 milyar batang atau lebih rendah dikenakan cukai 5 persen per tahun, sedangkan untuk SKT dengan tingkat produksi diatas 5 milyar batang dikenakan tarif cukai 17,5 per tahun.

\section{Pajak, pengeluaran pemerintah}

Semenjak Orde Baru pemerintah menyatakan tekadnya untuk menggunakan sistem anggaran pendapatan dan belanja yang seimbang (balanced budget). Anggaran berimbang dalam konteks ini dimaksudkan sebagai pemerintah tidak melakukan pinjaman kepada Bank Sentral atau tidak melakukan pencetakan uang untuk membiayai semua pengeluarannya. Hal ini tercermin dari struktur APBN di mana belanja negara dibeayai oleh penerimaan dalam negeri dan penerimaan pembangunan (penerimaan dari hutang luar negeri). Dalam pengertian yang paling ketat sebenarnya struktur APBN 
seperti itu dimana masih terdapat unsur pinjaman luar negeri, APBN itu disebut menganut APBN yang defisit. (Budiono,' 1984). Tetapi dengan menggunakan pengertian yang longgar, struktur APBN Indonesia masih bisa disebut sebagai berimbang karena tidak melakukan pencetakan uang oleh pemerintah (meminjam dari bank Indonesia).

Sementara itu dalam analisis ekonomi makro terutama analisis multiplier effect, keseimbangan anggaran (defisit, surplus, berimbang) dilihat dari seberapa besar pengeluaran pemerintah (G, Government Expenditure) bisa dibeayai dari penerimaan dari pajak. Apabila pajak yang ditarik dari masyarakat semuanya digunakan untuk (dan sama dengan) pengeluaran pemerintah, maka ia disebut menganut anggaran berimbang. Apabila penerimaan pajak tidak mencukupi pengeluaran konsumsi pemerintah, disebut menganut sistem anggaran defisit dan apabila pajak yang ditarik melebihi pengeluaran pemerintah maka ia disebut sebagai anggaran surplus. (Boediono, 1984). Dengan mengabaikan pajak dari minyak yang sebagian besar merupakan pajak atas perusahaan asing, maka kita bisa melihat sistem anggaran yang "sebenarnya" dianut di Indonesia. Meskipun anggaran Indonesia disebut sebagai anggaran berimbang, tetapi ternyata untuk kepentingan analisis pengganda anggaran kita tidak selalu demikian, sebagaimana bisa dilihat dari tabel.

Tabel 5 : Penarikan Pajak, Pengeluaran Pemerintah, 1969 - 1990 (dalam milyar Rp)

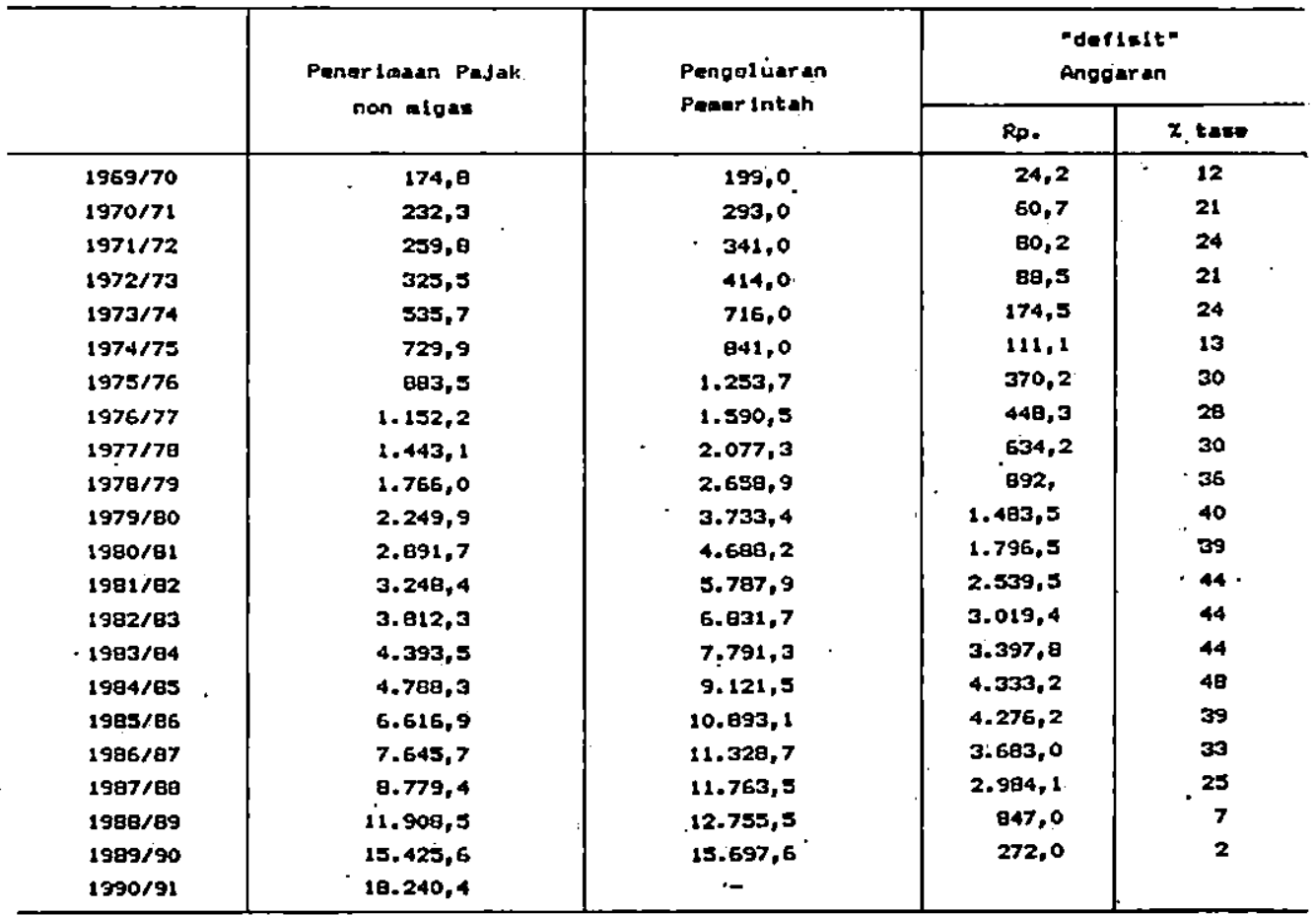

Sumbars Nota keuangan. 1990 
Dari tabel nampak bahwa dari sisi keseimbangan anggaran dalam pengertian yang "mumi", anggaran pendapatan dan belanja ternyata menunjukkan anggaran yang tidak seimbang dalam arti defisit. Pengeluaran pemerintah selalu tidak bisa dibeayai hanya dengan penerimaan dari pajak saja, tetapi mesti ditambah dengan sumber lain di luar pajak. Pada tahun 1969 terdapat defisit yang relatif rendah yaitu 12 persen dari total pengeluaran. $\mathrm{Hal}$ ini karena memang tidak terdapat sumber dari sektor luar negeri yang berarti. Defisit itu semakin lama semakin membengkak sampai angka antara 30-45 persen antara tahun 1977-1986. Tetapi dalam dua tahun terakhir tingkat defisit anggaran belanja pemerintah mengalami penurunan masingmasing hanya 7 persen pada tahun 1988 dan 2 persen untuk tahun 1989. Hal ini dikarenakan penerimaan dari pajak yang memang terus meningkat. Hal ini menunjukkan adanya kemandirian dalam perekonomian Indonesia pada tahun-tahun terakhir.

\section{Reformasi pajak}

Dari uraian terdahulu bisa dilihat dua hal. Pertama, adanya kenyataan bahwa sebenamya anggaran Belanja Indonesia untuk analisis multiplier adalah defisit, dengan menggunakan kriteria terketat. Kedua, terdapat usaha pemerintah yang cukup intensif untuk meningkatkan peran pajak sebagai tulang punggung perekonomian Indonesia. Upaya itu nampak hasilnya dari peningkatan penerimaan dari pajak yang semakin tinggi sehingga persentase pajak untuk penerimaan pemerintah semakin membesar. Apakah dampak dari intensifikasi penarikan pajak itu terhadap anggaran defisit? Apakah dampaknya terhadap aktifitas ekonomi dalam masyarakat?

Meskipun dalam struktur resmi APBN kita yang seimbang peningkatan penerimaan dari pajak itu tidak akan mengubah keseimbangan anggaran, tetapi karena kita melihat ada defisit anggaran dalam APBN, maka peningkatan penerimaan dari pajak sebagai akibat dari reformasi di bidang perpajakan yang disertai tekad yang kuat untuk melaksanakan reformasi akan memperkecil defisit anggaran. Persentase anggaran belanja pemerintah untuk membeli barang dan jasa yang berasal dari penerimaan pajak akan semakin meningkat.

Apabila penerimaan pajak semakin menuju keseimbangan dengan pengeluaran pemerintah maka hal ini mempunyai konsekuensi multiplier effect dari perekonomian menjadi semakin mengecil dan ceteris paribus akan mendekati multiplier effect dari anggaran berimbang $(=1)$. Hal ini berarti dengan intensifikasi penarikan pajak maka gejolak perekonomian akibat terjadinya perubahan variabel ekonomi dalam perekonomian akan semakin mengecil. Kebijaksanaan yang sifatnya ekspansif akan menyebabkan meningkatnya aktifitas ekonomi dalam tingkatan yang lebih rendah. Sebaliknya adanya kebijaksanaan kontraksi akan menyebabkan penurunan aktifitas ekonomi tidak akan secepat apabila penarikan pajak tidak intensif. 


\section{Daftar Pustaka}

Bank Indonesia, Laporan Keuangan BI, beberapa tahun penerbitan.

Boadway, Robin W dan David E Wildasin, Public Sector Economy, Litlle Brown and Company, Boston, Toronto, 1984

Bransson, William H, Macroeconomic Theory and Policy, Harper and Row Publishers, New York, 2nd edition, 1979.
Guritno Mangkusubroto, Ekonomi Publik, BPFE UGM, Yogyakarta, 1985

Musgraave, Richard A dan Peggy B Musgrave, Public Finance, Theory and Practice, Macgraw Hill, 1987

Uppal, JS, "The Indonesian Tax Strustur" dalam Ekonomi Keuangan indonesia, vol XXXIV, Nomer I, tahun 1986

Nota Keuangan RI, 1991/1992 